研究論文

\title{
空気圧シリンダシールの摺動・非摺動状態の判別と制御*
}

\author{
吉 満 俊 拓**, 小 山 紀***
}

\section{Discrimination and Control of a Pneumatic Cylinder under Stick or Slide mode of seal}

\author{
Toshihiro YOSHIMITU, Osamu OYAMA
}

The pneumatic cylinder has internal rubber seals. When the piston moves toward the desired position, the seal sticks and slides and then attaches itself to the cylinder wall or piston rod, near the final position. Therefore the viscoelastic formation of the seal occurs, witch has effects on control performances, such as positioning accuracy, stability and settling delay in this region. Combination of stick and slide mode control models is necessary to execute highly stable and accurate control of a pneumatic cylinder, but these modes can not be observed directly.

In this report, a method is proposed for discriminating whether the seal sticks or slides in real time and for its control by choosing and switching between slide or stick modes. The control performance is specified experimentally.

Key Words: Pneumatic cylinder, Position servo system, Piston seal, Viscoelasticity, Modeling, Optimal control

\section{記号}

本報告で用いる記号をまとめて示す.

$A_{v}, b_{v}$ : 摺動モデルの特性を表す行列,

$A_{s}, \quad b_{s}$ : シリンダの受圧面積 $\left(\mathrm{m}^{2}\right)$

$D_{v} \quad$ : 摺動モデルの粘性摩擦係数 $(\mathrm{Ns} / \mathrm{m})$

$D_{s} \quad$ : 粘弾性モデルの粘性摩擦係数 $(\mathrm{Ns} / \mathrm{m})$

$e(h) \quad$ : 目標位置とシリンダ位置の誤差 $(\mathrm{m})$

$f_{0} \quad$ : 最適フィードバック係数行列

$F_{r}$ : 摺動モデルの摩擦力 $(\mathrm{N})$

$F_{r} \quad$ : 粘弾性モデルの摩擦力 $(\mathrm{N})$

$k \quad:$ ばね定数 $(\mathrm{N} / \mathrm{m})$

$K_{p}, K_{i}$ : 比例動作, 積分動作の係数

$M$ : ピストン可動部質量 $(\mathrm{kg})$

$R(h)$ : 目標位置 $(\mathrm{m})$

$v(h) \quad$ : シリンダ速度 $(\mathrm{m} / \mathrm{s})$

$u(h)$ : サーボ弁への制御入力 $(\mathrm{V})$

$x(h)$ : シリンダ位置 $(\mathrm{m})$

$S_{i}(l) \quad:$ ニューロン

$W_{i j}(l)$ : シナプス結合

$d_{i} \quad$ : 教師信号

*平成 13 年 8 月 1 日 原稿受付

**神奈川工科大学福祉システム工学科

(所在地 テ243-0292 神奈川県厚木市下荻野1030)

yosimitu@ne.kanagawa-it.ac.jp

***明治大学

(所在地 $\bar{\top} 214-0033$ 神奈川県川崎市多摩区東三田 1-1) oyama@isc.meiji.ac.jp
$\begin{array}{ll}G & : \text { ゲイン } \\ T & : \text { 時定数 }(\mathrm{s})\end{array}$

\section{1. 緒言}

空気圧シリンダは軽量コンパクトで大出力が得られる事 からさまざまな分野で使用されている. しかし，使用方法 はシリンダストロークの一部あるいは全体を用いた 2 点 間PTP (Point To Point) の使用方法がほとんどである. しかし, エレクトロニクス技術の発達と空気圧サーボ弁の 開発によって，フィードバック制御を用いた空気圧サーボ システムが実現化された ${ }^{122)}$. 空気圧シリンダの変位はシ リンダの内圧に支配されており，サーボアクチュエータと して高精度な位置・速度動作をさせるためには高精度・高 応答な圧力制御が必要となる。このような目的でサーボ弁 は幾種類かのものが開発されており精度や応答性が改善さ れてきている.これらのサーボ弁を用いた研究として, フィードバック系を用いたWONGら ${ }^{3)}$ や適応制御を用いた 竹下ら ${ }^{4)}$, 外乱オブザーバを用いた則次ら ${ }^{5)}$ や, サーボ弁 と人工筋アクチュエータを開発した青木ら ${ }^{6}$ がある.サー ボ弁を用いた場合制御系の次数が高くなりサーボ弁自体お よび空気圧のシリンダの摩擦や特性の非線形などの影響を 強く受け易い. このため橋本ら ${ }^{7)}$, 早川ら ${ }^{8)}$, 栗田ら ${ }^{9}$ 富沢

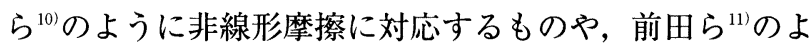
うにディザを使用するなどの方法がある．いずれにしても 制御系は機器特性の数学モデルを組み込んで設計される. しかし, 空気圧シリンダによる位置・速度制御は依然とし て旧来の方法がとられ，これらの多くの有用な研究が実用 化されたとは認めがたい.アクチュエータ形式の棲み分け 論議が過熱してきたこともあるが, 空気圧シリンダの制御 
性能に対する正しい評価や性能改善が必要であることに変 わりはない. シリンダの高度な制御を困難にしているのは, 空気圧シリンダの特性モデルを正確に得ることが困難であ ることによる.シリンダの定速移動時については $\mathrm{KAGAWA}^{12)}$ らにより有用なモデルが提案されているが， 位置制御精度に決定的な影響を与える停止位置近傍におけ る確立されたモデルは皆無である。一般的な空気圧シリン ダの内部には，空気漏れを防止するためのシールが取り付 けてあるが，従来から空気圧シリンダのモデルはシールが 滑っている状態（摺動状態）に対してのみ考えられてきた。 しかし空気圧シリンダによる位置決めの場合，その行程に おいてシールがシリンダ内部を滑っている状態 (摺動状態) と滑らずシリンダの内壁に固着し弾性変形している状態

（非摺動状態）があり，それぞれの状態では異なった特性 を有す.

荒木ら ${ }^{13)}$ がシールの摩擦がシリンダに与える影響につい て調べているが理論的な裏づけがされていない，従来シー ルに起因する特性を積極的に用いたものは皆無であったが， 小山ら ${ }^{14)} ら に よ り$ 粘弾性領域におけるピストン変位の特性 モデルの解明およびこれを用いた制御性能の向上が報告さ れた。

前報 (1)ではシールの非摺動状態のみを対象としていたが 非摺動状態の制御と従来の摺動状態のみを考慮した制御を 効果的に組み合わせて行うことができれば，シールとシリ ンダ間の摩擦力に起因する位置決めの困難さを回避するこ とができ, 空気圧シリンダの低コストを活かしながら, 精 度の良い位置決めが期待できる。

以上の観点から本研究では，摺動状態と非摺動状態のど ちらの状態であるかをリアルタイムに判別する手法を明ら かにしこれにより 2 つの特性モデルを切り替えて有効な 制御を実行する。

\section{2. シリンダ変位の特性モデル}

従来，空気圧シリンダの特性モデル（摺動モデル）とし て必ずFig. 1のものが用いられる.

このモデルはシール部で発生する粘性摩擦係数c・によ り生じる粘性摩擦力を表したものとなっている. しかし, 位置決め点近傍ではシールが粘着するため粘弾性モデル （非摺動モデル）を考慮する必要がある。この場合，摺動 モデルと大きく異なる点は, シール弾性の影響が現れてく ることと，粘性がシールの物理的性質に起因するものであ るから摺動時と特性值が全く異なることである.

粘弾性モデルとして複数のばねとダンパの組合せが使わ れることもあるが，実用的なモデルとしては単純なものほ ど有用であるため，Fig. 2に示すような 1 個のばねダンパ からなるKelvinモデルで近似することが有効であること を前報で示した ${ }^{14}$.

ここでは，シール特性が持つヒステリシスによる動作点

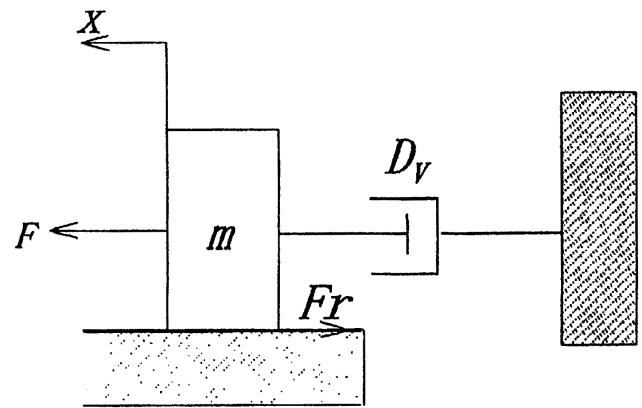

Fig. 1 Conventional model of pneumatic cylinder

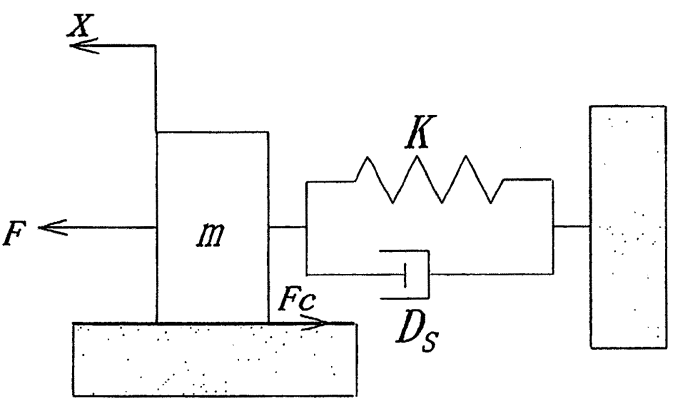

Fig. 2 The Kelvin model

のずれおよび不感帯を表すため，等価的なクーロン摩擦力 Frを導入している．ただし，直列ばね 2 個とダンパによ る 3 素子モデルとも比較し, 有為な違いがないことを確 認している.

\section{3. 実験装置}

本研究で使用した実験装置の概略をFig. 3に示す。この 装置は空気圧シリンダと 2 つの 3 ポートサーボ弁より構 成され，コンピュータからの電気信号を $\mathrm{D} / \mathrm{A}$ 変換器によ り電圧に変換し，サーボ弁を駆動させて流量を制御するこ

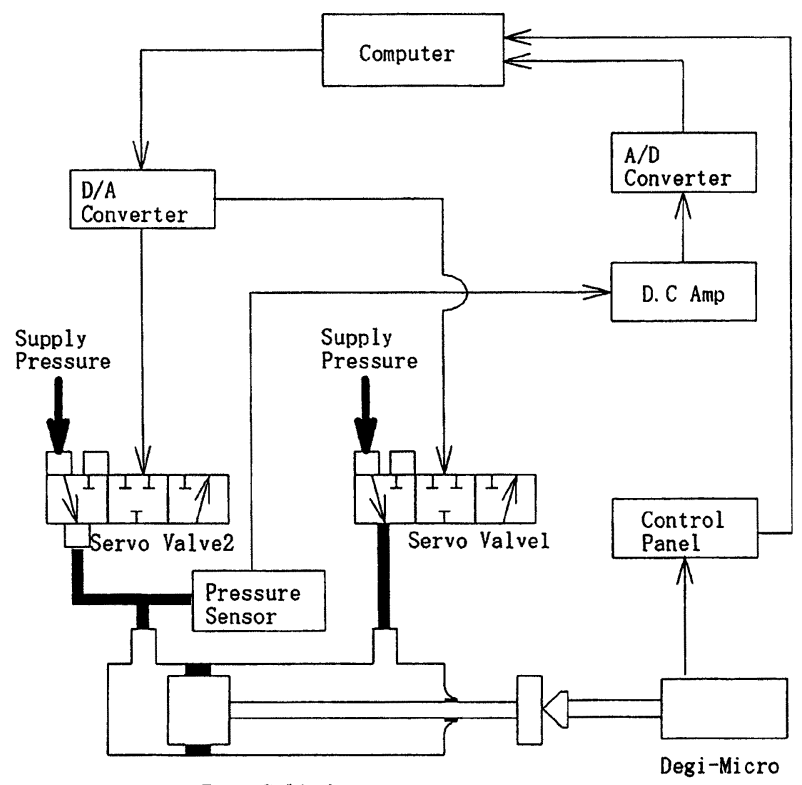

Test Cylinder

Fig. 3 Scheme of experimental setup 2002 年 5 月（平成 14 年) 
とにより圧力を変え, シリンダ駆動力としている.この時, シリンダのロッド側の圧力は一定とし，ヘッド側室内圧力 は任意の圧力となるよう, 半導体圧力センサーを設置し, この值を $\mathrm{A} / \mathrm{D}$ 変換器を介して, コンピュータにフィード バックしている. シリンダ変位は, デジマイクロカウンタ （分解能 $0.1 \mu \mathrm{m}$ ）を使用し計測している. 試料としては 従来から一般に使用されているニトリルゴムをシール材に したシリンダを用いて実験を行った。またシリンダ内径は 40.0mm，ストローク $100.0 \mathrm{~mm}$ である.

\section{4. 制御モデルのパラメータ同定}

実験により求められた摺動・非摺動モデルの各パラメー 夕, バ六俰数 $k$ と粘性摩擦係数 $D$ 及び最大静止摩擦力 $F$ を Table 1にしめす. 非摺動モデルではシールが粘着してい

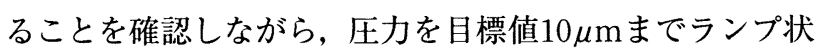
に変化させたときのシリンダ変位より求めた．摺動モデル

Table 1 Seal characteristics

\begin{tabular}{|c|c|c|c|}
\hline & $\begin{array}{c}\text { バネ係数 } \\
k\left[\times 10^{2} \mathrm{kN} / \mathrm{m}\right]\end{array}$ & $\begin{array}{c}\text { 粘性摩擦係数 } \\
D[\mathrm{kNs} / \mathrm{m}]\end{array}$ & $\begin{array}{c}\text { 最大静止摩擦力 } \\
F[\mathrm{~N}]\end{array}$ \\
\hline 非摺動時 & 7.34 & 632 & 0.894 \\
\hline 摺 動 時 & & 0.326 & 0.894 \\
\hline
\end{tabular}

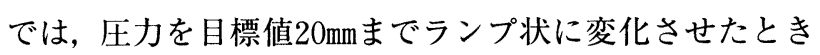
のシリンダ変位より求めた.

\section{5. 摺動・非摺動状態の判別法}

シールの摺動・非摺動状態を制御中にリアルタイムに判 別する方法として, シリンダの速度による判別と，ニュー ラルネットによる判別の 2 種を採用しその有効性を検討 した.

\section{1 摺動および非摺動モデル}

前報 14 で示された様に位置決め点近傍ではシールの伸び に起因するバネ特性は線形となり, また速度が遅いので容 積変化も微小であるなどにより制御モデルは線形系で近似 する. 状態変数を, サーボ弁入力を $\mathrm{x}(t)=[x(t), v(t), p$ $(t)])^{\mathrm{T}}$, サーボ弁入力を $u(t)$ として, 状態方程式は摺動 モデルでは

$$
x(t)=\left(\begin{array}{ccc}
0 & 1 & 0 \\
0 & -\frac{D_{s}}{M}-\frac{A}{M} \\
0 & 0 & -\frac{1}{T}
\end{array}\right) x(t)+\left(\begin{array}{c}
0 \\
0 \\
\frac{\mathrm{G}}{T}
\end{array}\right) u(t)-\operatorname{sgn}(v(t)) F_{c}
$$

非摺動モデルでは

$$
x(t)=\left(\begin{array}{ccc}
0 & 1 & 0 \\
-\frac{k}{M}-\frac{D_{v}}{M}-\frac{A}{M} \\
0 & 0 & \frac{1}{T}
\end{array}\right) x(t)+\left(\begin{array}{c}
0 \\
0 \\
\frac{\mathrm{G}}{T}
\end{array}\right) u(t)-\operatorname{sgn}(v(t)) F_{v}
$$

となる．また，前報で示した様に位置決め点では粘弾性の 効果が支配的となるので，摩擦力 $F_{r}, F_{c}$ は余り大きくない として無視し零次ホルダで離散化した状態方程式をそれぞ れ

$$
\begin{aligned}
& \mathrm{x}(h+1)=A_{s} \mathrm{x}(h)+b_{s} u(h) \\
& \mathrm{x}(h+1)=A_{v} \mathrm{x}(h)+b_{v} u(h)
\end{aligned}
$$

とした。制御は線形最適制御とした 1 型のサーボ系を構 成したとき偏差系

$$
\begin{aligned}
& \mathrm{x}_{e}(h+1) \\
& u_{e}(h+1)
\end{aligned}=\left(\begin{array}{ll}
\mathrm{A} & \mathrm{b} \\
\mathrm{O} & 0
\end{array}\right)\left(\begin{array}{l}
\mathrm{x}_{e}(h) \\
u_{e}(h)
\end{array}\right)\left(\begin{array}{l}
0 \\
1
\end{array}\right)(h)
$$

に関する評価式

$$
J=\sum_{h=0}^{\infty}\left\{\left(\begin{array}{l}
\mathrm{x}_{e}(h) \\
u_{e}(h)
\end{array}\right) \mathrm{T} \quad \mathrm{Q}\left(\begin{array}{l}
\mathrm{x}_{e}(h) \\
u_{e}(h)
\end{array}\right)+r v^{2}(h)\right\}
$$

を最小とする最適サーボ入力

$$
u_{e}(h+1)=v(h)=-f_{o}\left(\begin{array}{l}
\mathrm{X}_{e}(h) \\
u_{e}(h)
\end{array}\right)
$$

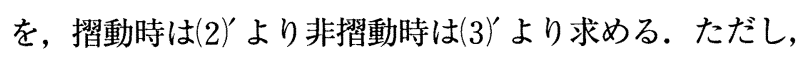
$\mathrm{x}_{e}(h)$ および $u_{e}(h)$ は定常值からの偏差を意味する.

\section{2 速度による判別}

計測されたシリンダの摺動速度がしきい值以上の時にシ リンダは摺動しているものとして摺動モデルを使い，しき い值以下の時に非摺動モデルに切り替えて制御する. しき い值を小さくすると殆どすべて摺動モデルのみで制御され， 逆にしきい值を大きくすると非摺動モデルを単独で用いた 場合と同じ傾向をとるようになる．前報より，シリンダの 非摺動範囲は $0.01 \sim 0.1 \mathrm{~mm}$ と仮定し, シリンダ摺動速度を $1 \sim 10 \mathrm{~mm} / \mathrm{s}$ 範囲で予備実験を行い, しきい值として 2 $\mathrm{mm} / \mathrm{s}$ を使用する.

$$
\begin{gathered}
|v| \leqq \alpha \rightarrow \text { Stick model } \\
|v|>\alpha \rightarrow \text { Slide model } \\
\alpha: \text { しきい值 }
\end{gathered}
$$

\section{3 ニューラルネットによる判別}

ニューラルネットによりシールの摺動・非摺動状態を推 定させ，これにより制御モデルを切り替える.ニューラル ネットワークによる摺動・非摺動状態判別システムの構成 をFig. 4に示す.

本研究では, アルゴリズムは, バックプロパゲーション 学習アルゴリズムを使用しており, 入力層・中問層 1 層・出力層の 3 層で構成された階層型ニューラルネット を使用している.

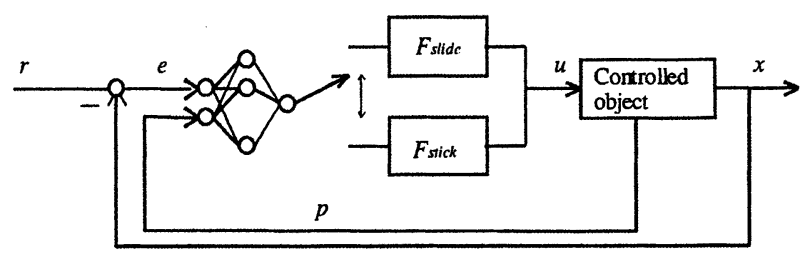

Fig. 4 Neural network model 
$l$ 層の $i$ ニューロン $s_{i}(l)$ の状態を示す式は

$$
s_{i}(l)=f\left(\sum_{j} w_{i j}(l) s_{j}(l-1)\right)
$$

であり, $w_{i j}(l)$ は $(l)$ 層と $(l-1)$ 層のニューロン間の情報を やり取りするシナプス結合, $f$ は 0,1 に飽和する非線形 関数である. 提示された教師信号と出力との誤差を

$$
E=\frac{1}{2} \sum_{i}\left(s_{i}(L)-d_{i}\right)^{2}
$$

と定義する. L は出力層の番号で $s(L)$ はネットワークの 出力を, $d_{i}$ は教師信号を示す. 出力誤差 $\mathrm{E}$ に最急降下法を 適応して得られるBP法のアルゴリズムより

$$
\Delta w_{i j}(l)=-\mu \frac{\partial E}{\partial w_{i j}(l)}
$$

(9)式に従って出力誤差を減少するようにシナプス結合を変 更し収束するまで繰り返す。 $\mu$ は学習係数である.ネット ワークへの入力層には入手可能な物理データである圧力の 変化量 $\Delta p$ ・ シリンダの変位量 $\Delta x$ の 2 入力のパラメータを 学習パターンとして与え, 出力層には教師信号として摺動 状態を+ + ・非摺動状態をー 1 とする 1 出力とした. 学 習データは, 摺動時のデータはシリンダ速度が $3 \mathrm{~mm} / \mathrm{s}$ 以上 の時の圧力・シリンダ変位を用い, 非摺動時のデータは目 標值を $0.01 \mathrm{~mm}$ とた非摺動状態のシリンダ位置制御時の データを用いる．入力層と中間層とのシナプス結合には対 数シグモイドニューロンを, 中間層と出力層とのシナプス 結合には正接シグモイドニューロンを用いた. 重み係数お よびしきい值の修正方法については, 重み係数, しきい值 の学習係数は 0.01 とした. 出力層には摺動・非摺動状態 の判別結果が正 (摺動) - 負 (非摺動) の值として出力さ れる。また中間層は10個20個30個40個の場合で予備実験 を行ったところ，ネットワークが収束するのに十分と思わ れる20個を採用した。 ネットワークに学習パターンを 1000回ずつ掲示して, その時点でのテストパターンに対 する識別結果を得た。この学習識別を繰り返し, 教師信号 に対する平均 2 乗誤差が最小值に達した時, 学習を終了 する. 学習誤差は学習回数の増加に伴い, いったんは極小 值をとりがて小さい值に収束していくが, 汎か誤差は 10000回で極小值をとりその後若干だが上昇する. 10000 回以上の学習は過学習と考えられるため, 学習回数は 10000回とした。

\section{6. 実験結果}

目標を $20 \mathrm{~mm}$ ，制御モデルを切り替えることなく位置決 めを行った場合の実験結果をFig. 5，6に示す.

摺動モデルをもとに制御した結果では, 移動開始後約 4 秒で収束するが, 最大で $4 \mathrm{~mm}$ のオーバーシュートが発

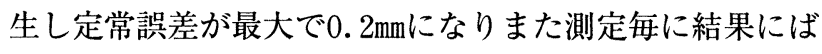
らつきがある. 最も定常誤差が少ない場合の結果をFig. 6 に示す. 目標值近傍でシールが摺動と非摺動を繰り返し整 定を妨げている. 非摺動モデルによる場合は, 目標値に対

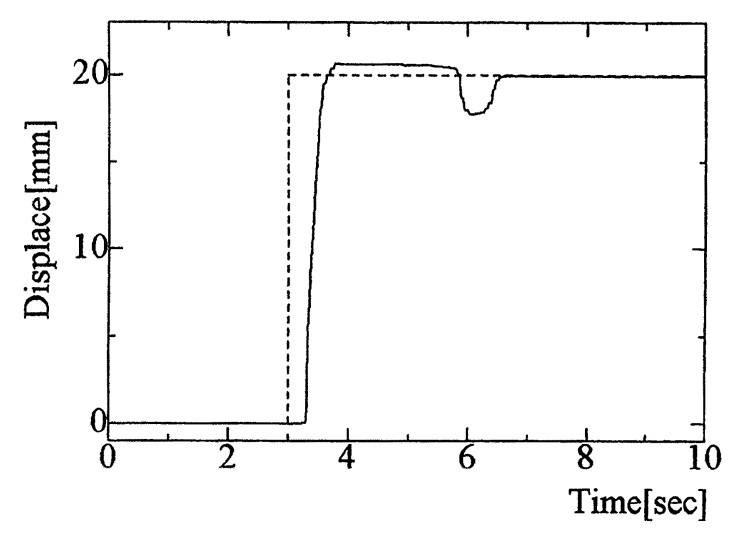

Fig. 5 Optimal Control using slide model

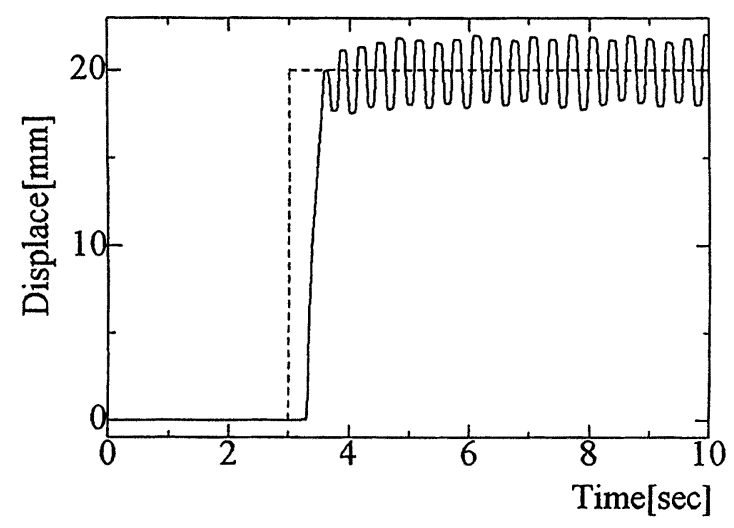

Fig. 6 Optimal Control using stick model

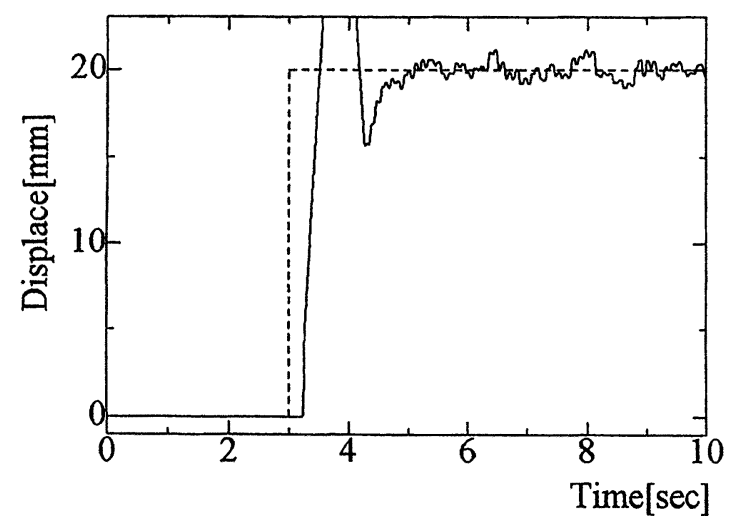

Fig. 7 Optimal Control using discrimination by velocity

し収束せず振動的となってしまった。

次に，速度によりモデルを切り替えて制御をした場合の 結果をFig. 7に示す.

目標值前後で微少な振動が発生している．速度情報のみ では，摺動・非摺動状態の判別が不可能であったためと考 えられる. 最後に, ニューラルネットにより摺動・非摺動 状態を判別した結果を示す．応答に乱れがなくスムーズに 切り替えが行われている，立ち上がり時間は，単独モデル を使用した場合に比べ10\%短くなり, 定常誤差は測定器 の検出限界以下となり, 良好な制御結果となった.

立ち上がり時間として目標値の $90 \%$ に達するまでの時 


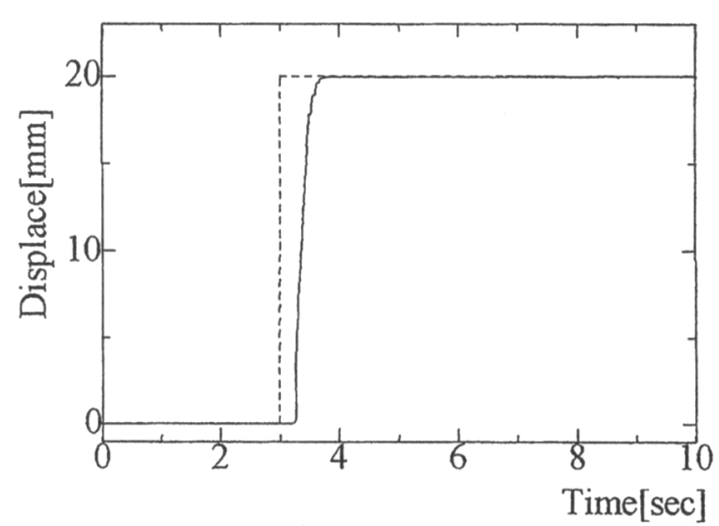

Fig. 8 Optimal Control using neural network

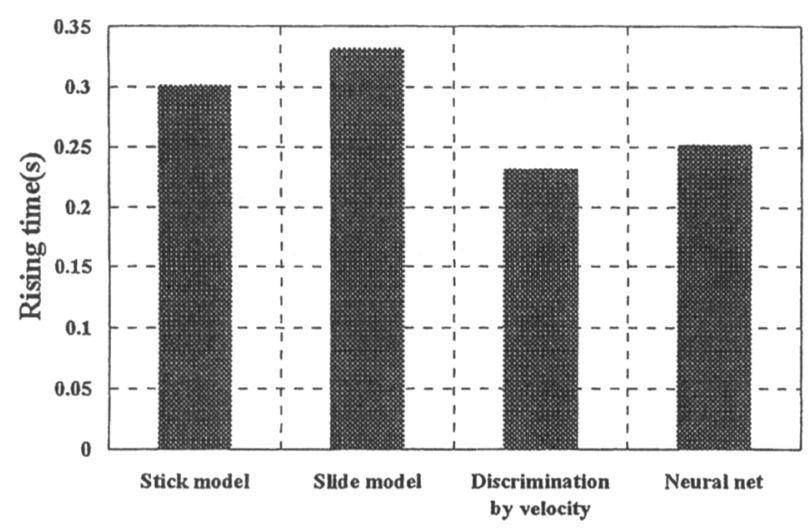

Fig. 9 Rising time

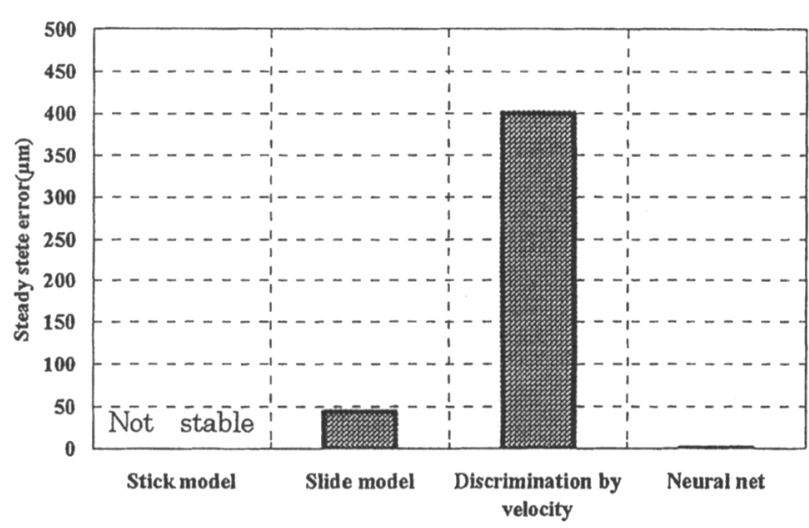

Fig. 10 Steady state error

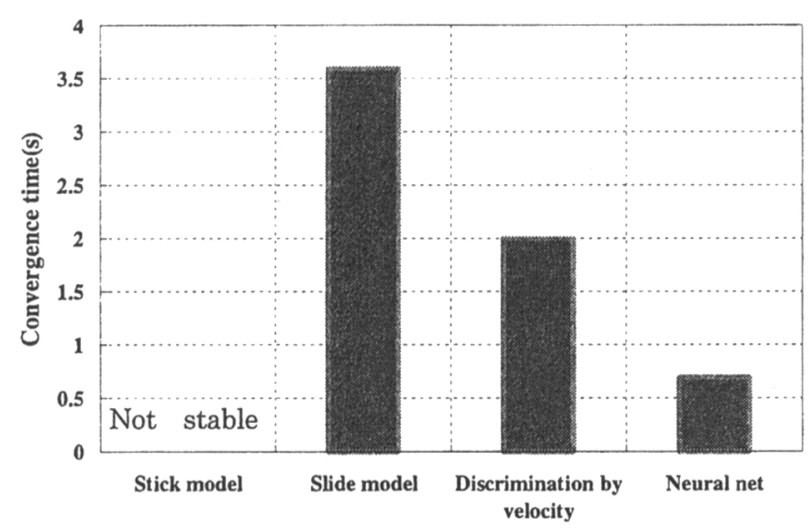

Fig. 11 Convergence time
間を比較した結果をFig. 9に示す. 速度およびニューラル ネットにより判別した場合, 単独モデルを使用した場合と 比較して立ち上がり時間が約 $20 \%$ 短縮できた。

次に, 目標値士 $2 \%$ 以内に収束した場合を整定とし, 定常誤差を比較した結果をFig. 10に示す.

非摺動モデルのみを使用した場合は整定せず定常誤差を 計測することはできなかった. 摺動モデル単独で制御した 場合，定常誤差は $48 \mu \mathrm{m}$ となったがばらつきが多く測定毎 に值が $200 \mu \mathrm{m}$ から $40 \mu \mathrm{m}$ の範囲で変化する，速度情報のみ で判別した場合, 一定値に整定しないので誤差の最大值を 記載した。ニューラルネットにより判別した場合定常誤差 は測定器の検出可能誤差以内となり他と比較して良好な制 御結果となった。

最後に，整定するまでの時間を比較した結果をFig. 11 に示す. 非摺動モデルのみで制御した場合整定しなかった ので記載していない. 他の 3 つを比較するとニューラル ネットによる判別が最大で約 $80 \%$ の時間短縮結果となっ た.

\section{7. 結論}

空気圧シリンダの位置決めを行う際, その行程において シールの状態は, 摺動状態と非摺動状態を繰り返す。特に 目標位置近傍に着目した場合, その状態はシリンダ速度が 十分遅くなっているために非摺動状態であると考えられる. したがって最終的な位置決め精度はシールの伸びにより決 定される状態であり，そのシールの粘弾性特性が重要とな る。

実用化のために摺動および粘着のふたつのモデルを切り 替えて制御をおこなうのが効果的であり，これにはシール の摺動状態, 粘着状態の判別が必要となる. 粘性摩擦係数 を実時間で観測あるいは推定しながら制御を実行したなら ば，この值が大きく異なることを利用して切り替えを実行 することが可能であると考えられ, 本研究ではこの判別法 としてまずシリンダの速度による判別を試みた. 立ち上が り時間の短縮化はできたがシリンダが目標值近傍で収束せ ずうまくいかなかった，そこでニューラルネットを使用し てリアルタイムでのシールの摺動状態, 粘着状態を判別が 可能であることを示した.

\section{参 考 文 献}

1) 則次 : 空気圧制御の新しい展開, システム/制御／情 報, 39-2，67/73，（1995）

2 ) 鹿島: 直動空気圧サーボ弁による制御例, 油圧と空気 圧, 26-2, 70/74, (1995)

3 ) WONG, PU, MOORE: Methods of Overcoming Friction Effects in the Control of Pneumatic Servo Systems, Am Soc Mech Eng Fluid Power Syst Technol Div, 2, 139/144, (1995) 
4）竹下, 田中, 清水, 柴田, 山本：空気圧サーボ采の最 小分散型適応極配置制御，日本機械学会全国大会講演 論文集，73-4，300/301，(1995）

5 ）則次，高岩：外乱オブザーバを用いた空気圧サーボ系 のインピーダンス制御 計測自動制御学会論文集，30 -6, 677/684, (1994)

6）青木 橋本 今枝 喜羽：ニューラルネットワークに よるゴム人工筋アクチュエータの位置・カ制御，平成 10年秋季油空圧講演会講演論文集，112/114，（1996）

7 ）橋本 松熊 石田：非線形PID補償器による空気圧シ リンダの位置決め制御，平成 9 年秋季油空圧講演会 講演論文集，66/68，(1995)

8）早川 鴨山 永瀬：ライディングモード制御を用いた 空気圧アクチュエータ，平成10年春季油空圧講演会 講演論文集，55/57，(1996)

9）栗田 石田：スミス型むだ時間補償器を用いたI-PD 型適応極配置, 平成10年秋季油空圧講演会講演論文 集，133/135，(1998)
10）富沢，橋本，今枝，中川：ニューラルネットワーク補 償木を利用した空気圧シリンダの制御，平成13年春 季フルイドパワーシステム講演会論文集 $64 / 66$ (2001)

11）前田 川上 中野：空気圧リフタの位置制御：平成 9 年秋季油空圧講演会講演論文集，69/71，(1995)

12) T, KAGAWA M, SHIMAZU Y, ISHII: AIR TEMPERATURE CHANGE OF PNEUMATIC CYLINDER WITH METER-OUT CONTROL AND ITS EFFECT ON THE VELOCITY, FLUCOME '91 (1991)

13）荒木，棚橋：空気圧シリンダの摩擦がストローク特性 に及ほす影響，昭和 55 年秋季油空圧講演会講演論文 集, 23/26，(1980)

14）小山 紀，天野景範，飯塚健太呂，吉満俊拓：空気圧 シリンダ変位の粘弾性特性と制御性能への影響, 日本 油空圧学会論文集，29-7，19/24，1998 